\title{
Pakistan's emerging regional politico-economic role in the SCO
}

\author{
Tehmina Aslam*1 | Ilsa Tariq ${ }^{2}$
}

1. School of Integrated Social Sciences, The University of Lahore, Lahore, Pakistan.

2. Economics, Management and Social Sciences Program, London School of Economics and Political Science (LSE), University of London, United Kingdom.

*Corresponding Author Email: taranjha1@ gmail.com

\begin{abstract}
Shanghai Cooperation Organization (SCO) is presently a Eurasian politico-economic bloc having two South Asian members, Pakistan and India. The aim of the study was to evaluate the prospective role of Pakistan in the SCO with qualitative study based on interviews. On June 2017, Pakistan was granted permanent membership in the SCO during its $16^{\text {th }}$ Heads of State Summit in Astana. By associating itself as a permanent member, summit allows Pakistan to contribute to regional development alongside other key regional players, Russia and China and India. The study gave four findings that how multilateralism was having a calming effect on a regional conflict, Pakistan embracing independence from isolation through Trans-Afghanistan gas pipeline. Through CPEC, Pakistan was offering the SCO member countries an economic hallway. And how the Eurasian politico-economic ambitions to reach the warm waters of the Arabian Sea was perceived as hampering the Western economic interests, thereby offering a major impediment to Pakistan's emerging role in the SCO. Moreover, SCO participation will help enhance Pakistan's worldwide socio-economic objectives. This study examines the socio-politico and economic aspirations of Pakistan and benefit due to ties with $\mathrm{SCO}$ member countries.
\end{abstract}

Article History

Received:

March 16, 2021

Revised:

September 24, 2021

Re-revised:

October 13, 2021

Accepted:

October 15, 2021

Published:

October 25, 2021

Keywords: South Asia, Pakistan, China, India, Russia, Shanghai Cooperation Organization, SCO, Eurasia, multilateralism, regional cooperation.

How to Cite: Aslam, T. \& Tariq, I. (2021). Pakistan's emerging regional politico-economic role in the SCO. Liberal Arts and Social Sciences International Journal (LASSIJ), 5(2), 159-177. https://doi.org/10.47264/idea.lassij/5.2.11

Publisher's Note: IDEA PUBLISHERS (IDEA Publications Group) stands neutral with regard to the jurisdictional claims in the published maps and the institutional affiliations.

Copyright: @ 2021 The Author(s), published by IDEA PUBLISHERS (IDEA Publications Group).

Licensing: This is an Open Access article published under the Creative Commons AttributionNonCommercial 4.0 International License (http://creativecommons.org/licenses/by-nc/4.0/) 


\section{Introduction}

The Shanghai Cooperation Organization (SCO) is a significant development in global and regional politics. The SCO might help battle terrorism, separatism, and extremism in the area. Terrorism, separatism, extremism, and economic devastation plague Pakistan. The Kashmir dispute is a major concern for both countries (Zeb, 2018). Pakistan should lead in resolving these issues. As a result, SCO members may collaborate with Pakistan to address regional issues, particularly in Afghanistan. Overcoming large-scale American and Western influence on the SCO platform would be a significant task for Pakistan. Thus, the SCO and Pakistan benefit each other.

The SCO has become a regional and global powerhouse. Experts in the West regard the SCO as a danger to US interests; some say it's the beginnings of a new Warsaw Pact-style organization (or a "NATO of the East"). The SCO was founded in 1996 by China, Russia, Kyrgyzstan, Kazakhstan, and Tajikistan. The SCO was formed in 2001 when Uzbekistan joined the Shanghai Five. In 2005, Pakistan, India, Iran, and Mongolia joined (Aris, 2013). To enhance relations with regional nations, Pakistan joined the SCO in June 2017. It hopes to learn from and contribute to the SCO's Regional Anti-Terrorist Structure (RATS). However, despite Pakistan and India's strong push for SCO membership. In recent years, while Moscow backed New Delhi's request for SCO membership, Beijing, the SCO's most powerful state, backed Pakistan. During its 2015 meeting in Ufa, Russia, the SCO included Pakistan and India as members. In 2016, India and Pakistan signed an MoU. In addition to the SCO's ability to operate as a regional alliance, the depth of this conflict and its impact on the SCO are crucial concerns. However, Pakistan's main worry is what it can provide to the SCO and what it may get from membership.

During the previous 16 years, the Shanghai Cooperation Organization (SCO) has provided a fresh push to regionalism. It was formed as a result of talks between China and the Central Asian Republics (CARs). In the 1980s, Russia and China were recovering from the democratic collapse of the 1960s and moving toward cautious normalization. On the other side, the CARs were dealing with state-building obstacles, including border security issues. One of the most difficult difficulties for the CARs, China, and Russia was reaching an agreement on disputed and indefinite boundaries. The success of the European Union (EU) inspired several regions of the world to form alliances based on shared political visions and economic benefits (Johnston, 2017). The experiment of the EU offers two challenges to surmount. First, the major challenge faced by the EU was border disputes without resolution, which a politico-economic association remained a far cry. Second, the next challenge, as was faced by the EU, is the idea of developing a single internal market through standardizing laws applicable to member states by consensus. Most intent to forge any politico-economic association is deterred by these challenges.

The area comprising Central Asia was no exception to this rule. The Cold War (1947 - 1991) kept Central Asia divided (Steinberg et al., 2014) Two major regional countries, the former Union of Soviet Socialist Republics and the People's Republic of China, remained in opposite camps, despite sharing the socialist ideology. The dismemberment of the former Soviet Union into Russia, Central Asian Republics (CARs), and East European countries not only dented the communist ideology of Russia but also made it do some introspection to fathom the failure. Russia, the reduced version of the former Soviet Union, considered Eastern Europe and Central Asia its sphere of influence (Johnston, 2017). Nevertheless, the failure of the communist ideology in 1991 in keeping the pro-communist countries together made Russia think of an 
alternate strategy, if not ideology. Consequently, immediately after 1991, Russia formed a politico-economic alliance in the areas that once comprised the former Soviet Union.

In Central Asia, the major obstacle before Russia to form any politico-economic organization was the abysmal mistrust amongst the countries towards it. Consequently, Russia had to take an initiative in this regard to (a) assure its Central Asian neighbors of its intentions not to intervene in their internal affairs on any pretext whether it is humanitarian or protecting human rights; and (b) assure its Central Asian neighbors of respecting their independence, sovereignty and territorial integrity.

This time, Russia wanted to go beyond the Cold War compulsions to appease China. Russia and China had disputes on Islands. In 1991, Russia initiated efforts and, in 1994, it became able to resolve its border disputes with China on several hundred Islands on the Argun, Amur and Ussuri rivers (Weitz, 2008). On 26 April 1996, Russian became successful in persuading some of Central Asian States (such as Kazakhstan, Kyrgyzstan and Tajikistan) and China to form the Shanghai Five, which entered into a pact called the Treaty on Deepening Military Trust in Border Regions (Ahmad, 2017). This was the first milestone Russia achieved to realize the dream of forging a regional association based on mutual trust. To further the process, in April 1997, the Shanghai Five signed a pact of mutual confidence called the Treaty on Reduction of Military Forces in Border Regions. Now, the space was open for Russia to embrace China.

The Shanghai Five was the success of Russia's President Boris Nikolayevich Yeltsin and China's President Jiang Zemin, who on 27 May 1997 signed a declaration on the presence of a multipolar world (Turner, 2009). The Sino-Soviet spirit of mutual cooperation continued down the generations. In July 2001, Russia and China signed the Treaty of Friendship or the Treaty of Good-Neighborliness and Friendly Cooperation (Tyler, 2001). On 15 June 2001, the Shanghai Five experienced the first expansion when Uzbekistan joined the Shanghai Five, and the organization was named the SCO (Sayed, 2017). On 19 September 2003, the SCO was practically made active.

\subsection{Pakistan's concept of regionalism}

As a result of its geographic location at the crossroads of Central Asia, the Southern and Western Asian regions, Pakistan stands apart. Similarly, from a geo-vital, geo-political, and socio-economic standpoint, Pakistan's certificates are outstanding. Pakistan has a special relationship with the nations of the Shanghai Cooperation Organization, particularly the landlocked Central Asian states of Xinxiang, China's province in Afghanistan, and the states of the south, such as the Bedouin Sea and the Middle Eastern states. Pakistan also borders the Indian Ocean. There are no better examples of this than Pakistan's unique geography. Up to Gwadar, Pakistan is willing to take important work for the growing north-south trade and a vitality route with promising opportunities.

The recent agreement between China and Pakistan on constructing the Kashghar - Gwadar Street Rail System is a step forward in the right direction for each territorial partner. Pakistan, a country with a severe lack of energy, is seeing an increase in people requesting more energy. Right today, important national issues are classified as "vitality emergencies. It implies losing one's energy on an eternal basis for Pakistan to join the SCO. Currently, the Afghan pipeline project known as TAP would be considered a success (Nisa et al., 2021). 


\subsection{The Shanghai Cooperation Organization (SCO)}

The SCO is a Eurasian organization with official languages of Russian and Chinese. The main objective is forming a politico-economic association to do regional trade, though the element of mutual security (or a security alliance) also exists, making it the Russian-led Collective Security Treaty Organization. (Johnston, 2017) The focus is on infrastructural development for transportation and energy such as rail and road network, gas pipelines, electricity poles, etc._In July 2005, Pakistan, India, Iran, and Mongolia secured the observer status at the SCO summit in Astana, Kazakhstan (Ziauddin, 2017). In October 2007, the SCO signed an agreement with the Collective Security Treaty Organization (CSTO) to cooperate on issues such a security, crime and drug trafficking (Johnston, 2017). On 21 July 2008, Russia became able to resolve all its border disputes with China (Chan, 2008).

In 1995, Russia initiated efforts to resolve its border disputes on Islands with China and, in 2008, Russia became able to do so. In this way, it took both Russia and China about thirteen years (1995-2008) to settle their border disputes which had kept them alienated from each other during the Cold War despite the fact that both countries were the followers of socialism. Similarly, in 1996, Russian started establishing a regional cooperation with China and finished doing it in 2001. In this way, it took both Russia and China five years (1996-2001) to construct a dependable regional alliance.

In 2015, the SCO experienced second expansion to swell its membership to eight. In July 2015, the process of the inclusion of Pakistan and India as full members started in Ufa, Russia. In June 2016, Pakistan and India signed the memorandum of obligations to join as full members. On 9 June 2017, Pakistan and India were approved as full members at the SCO summit in Astana, Kazakhstan (Rana, 2017). Retrospectively, in 2001, the SCO was founded and in 2016 Pakistan became its member. In this way, after fifteen years (2001-2016) of the formation of the SCO, Pakistan became a member of the SCO. Pakistan enjoyed the observer status for eleven (2005-2016) years. Currently, there are four observers (such as Afghanistan, Iran, Mongolia and Belarus) and six dialogue partners (such as Armenia, Azerbaijan, Cambodia, Nepal, Sri Lanka and Turkey) of the SCO. Out of six Central Asian Republics, Turkmenistan declared itself a neutral country not interested in joining the SCO.

\subsection{Pakistan's contributions}

Enrolment in the SCO has undermined the Indian diplomatic plan to isolate Pakistan. So, the Indian Government rebuked the other side for its misdeeds in Indian - Administered Kashmir and attempted to condemn Pakistan. Regional players, notably Russia and China, acknowledged Pakistan's dedication and struggled against the possibility of psychological repression inside and outside its borders. After Qingdao, Pakistan has a unique opportunity to expand its humane commitment. Building trust amongst persons should be pursued. In the SCO organization, encouraging dialogue with enemies, notably India and Pakistan, can help shape opposing mindsets. Pakistan has an open the door to help establish an environment of common bilateral interests and contribute to regional stability. Pakistan may also build effective cooperation energy in the political domain, commerce and economy, scientific development, cultural, education, vitality transportation, environmental protection, and other sectors after Qingdao. Each of these open doors promotes regional peace, security, and stability within a multipolar globe. The Gwadar deep-ocean port in Pakistan offers the quickest route to the oilrich Gulf Region. 
As a result, Pakistan may be a valuable regional trade and energy partner. The Chinese president's commitment of 30 billion Yuan (4.68 billion U.S. dollars) to the SCO for promoting streamlined trade and regional interconnection is another positive move that can benefit Pakistan economically. China has agreed to establish a special financing facility inside the SCO Inter-bank Consortium. The consortium was formed in 2005 to provide financial and banking services to SCO joint projects. Current regional cooperation focuses on economic growth, trade diversification, resourcing transport, mining, and vitality industries while fostering political adaptability. Asia, Europe, Africa, Oceania, and the Middle East are part of the OBOR initiative. Currently, has global ramifications, including for China and Pakistan, as well as for Afghanistan, Iran, Central Asian Republics, India, as well as the region. CPEC needs a shared vision to promote geographical links, people interaction, and cultural diversity. CPEC also intends to improve the mix via academic, cultural, and regional knowledge, increased commerce and enterprises, and more co-activity, resulting in a shared destiny, peace, and progress (Fayyaz, 2019).

\section{Theoretical framework}

In regionalism, a geographical region is the major focus of the investigation. It grants an area the same value and importance as a 'state.' It defines the tendency of economic-political integration within an area. In other words, if an area gets economically integrated initially, it will only become politically integrated afterward. The idea of regionalism also argues that while states within a region function and function as a unit (with interdependence at its heart), their sovereignty, distinctiveness, and independence are maintained. The EU is among the greatest instances of modern regionalism. Scholars disagree on whether regionalism is a useful or desirable organizing principle in international politics. After WWII, regionalism led to regional organizations like the EU, which many researchers, scholars, and academics have studied closely. Since then, the regionalist discourse has been praised for its promise and condemned for its limitations. However, regionalism is an established system for international politics in today's world, and its absence is impossible to envisage. This is seen in the ongoing economic growth of current organizational structures and norms (Khetran, 2019).

However, the new regional authorities altered the institutions to suit their demands. In many areas of the globe, regionalism has increased regional connectedness and interdependency, which is crucial for recognizing common goals at the regional scale. In the intricate structure of the global economic system, China's approach to comprehending regionalism is illuminating. A major SCO member, China decided to spread its economic gains with the region and the globe. Regionalism's multidimensionality has made it a suitable method for obtaining the benefit of regional resources and settling regional disputes. Pakistan can benefit from this idea by framing contemporary concerns regionally.

\section{Research methodology}

The aim of the study was to evaluate the prospective role of Pakistan in the SCO context. As a result, the purpose of this research study is to examine the possibilities of Pakistan's relations with the CARs, particularly now that Pakistan has been granted permanent membership in the SCO. This study will answer the following research questions: What economic gains may Pakistan get from the SCO? And how might Pakistan strengthen ties with CARs? The idea of regionalism would be utilized to examine the situation relating to Pakistan-CARs ties and what could be done to enhance them. A qualitative exploratory research study based on interviews 
was conducted. By standardizing open-ended questions, bias was reduced. Literature was also consulted as the secondary source. Triangulation was done and the thematic analysis was undertaken to examine the likely role of Pakistan in the SCO. An extensive literature review was done to identify key focus areas in line with the requirements of this, which was then used to identify key actors for primary data collection. Tools designed for primary data collection were formatted for focus group discussions (FGD) and key informant interviews (KII).

\section{Discussion}

In the shape of the SCO, the Sino-Soviet alliance serves both the main partner countries. The collaboration had given a chance to Russia to recover politically in the post-Cold War era and come out of its regional isolation, especially when the EU was reluctant to include Russia in its fold (Pedro \& Viilup, 2015). There are three dimensions to look at the SCO:

- The SCO is a product of Russia's initiative coinciding with China's intent to shed its Cold War strategy of conservatism.

- The SCO the extension of the Sino-Soviet alliance, is the expansion of Russia towards its East and of China towards its South.

- The SCO has offered both Russia and China a chance to come out of regional isolation, whether the isolation was self-imposed or otherwise.

Regionally, Russia has become successful in mending fences with China. Russia is in need of China owing to China's economic prosperity (especially after China joined the World Trade Organization (WTO) on 11 December 2001 (Pilger, 2016). Whereas China needs Russia's help in terms of supplying energy resources and distributing transport network for the movement of goods to and from Europe (Gallagher, 2016). After entering the WTO, China began purchasing and selling with the rest of the world at a breakneck pace.

In 2014, Russia and China signed a $\$ 400$ billion deal to build a $3000 \mathrm{~km}$ long pipeline to transport gas from Siberia to the coal-burning northeast of China. For energy-hungry China, the supply of Russian gas through the Polar Silk Road, to be finished by 2025, was imperative to fuel the economy while lessening dependence on coal and oil and gas that had to travel to China through vulnerable people sea routes. Russia remained the main supplier of oil and gas to Europe, but it decided to diversify its customers by including China into its market fold.

China wants to develop its western half in agriculture and industry and yearns to link it to the Arabian Sea through Gwadar, Pakistan (Paul, 2014). China's western half is the other leg of China's need-based paradigm to touch the warm waters of the Arabian Sea, the same warm waters the former USSR said to have aspired to reach after stepping in Afghanistan in 1979. In all its manifestations, the SCO is primarily a Russia-China organization, even if the alliance is short of being called a bloc. The prospective role of Pakistan in the SCO can be viewed in the following four ways.

\subsection{The SCO is in the formative phase}

The SCO is still a new experiment in Central Asia, especially between Russia and China, two large countries of Asia. Asif Durrani opines that the SCO is still formative and needs time to mature and prosper.Asif Durrani says: 
"The SCO is in the formative stages of its existence which has focused on cooperation in peace and security issues and fight against terrorism. However, it also envisages cooperation in trade amongst the member states which is picking up with the passage of time" (Durrani, 2020).

The SCO seems to have been facing a conflict in its objectives, as the SCO has joined both the politico-economic and security concerns. It is as if the SCO were both the EU and the NATO (Johnston, 2017). Conjoining the roles offers an internal challenge to the smooth functioning of the SCO. To reinforce this point, Jalil Abbas Jilani thinks that the SCO has taken upon itself a huge multifaceted task to perform. Jalil Jilani says:

"The SCO's success can be measured from the fact that over the past 20 years, the SCO member states have adopted close to 1500 documents through the consensus-based decision-making process in the organization. These documents pertain to cooperation in all spheres of life ranging from security and politics to socio-economic development, trade, science and technology, environment, humanitarian, cultural cooperation and people-to-people contact, etc. The focus is now on developing implementable action plan in various spheres, thus, bringing tangible benefits to billions of people living in the region" (Jilani, 2020).

The task is onerous as neither the Shanghai Five nor its developed version, the SCO, has any past experience in dealing with such issues. The planning is there but the main challenge is implementation of the plans.

\subsection{Multilateralism is calming regional conflicts}

Multilateralism - the participation of multiple countries to meet an objective - has taken precedence over bilateralism. The same has a calming effect on a regional conflict, whether between China and India or between Pakistan and India. Multilateralism offers three benefits (Haass, 2017). First, it is useful for domestic issues, but they have a global impact. Second, it helps to deal with collective challenges. Third, it opens space for relevant non-state actors such as non-governmental organizations to be included in a selected process.

The origin of the SCO itself has a calming effect on relations between Russia and China. Rabia Akhtar opines that the SCO is the product of the desire of both Russia and China to cooperate and converge. Rabia Akhtar says:

"The establishment of the SCO forum is a consequence of Sino-Soviet cooperation, or, at the very least, desire to cooperate. Indeed, the SCO has helped mitigate divergences and highlight convergences...The wide-ranging goals of the SCO have certainly allowed Russia and China to expand the gamut of their ties and leave behind the wounds of yesteryears" (Akhtar, 2020).

The SCO is dipped in reconciliation and dismissive of the issues stoking detestation amongst its member states. Nevertheless, Pakistan and India joined the SCO with their fronts loaded with the issue of the future of the State of Jammu and Kashmir, which is divided between Pakistan and India and has been waiting for the implementation of the United Nations Security Council Resolution number 47 urging upon both Pakistan and India to create conducive 
conditions for conducting a referendum to express their right to their self-determination (Cohen, 2016). In 1949, India brought Kashmir under Article 370 of its Constitution (Noorani, 2011). The Article granted a special autonomous status to the part of Kashmir held by India and permitted India to look after the defense, foreign affairs, and communication. On 5 August 2019, India unilaterally revoked Article 370 and related Article 35-A to deny the autonomous status to Kashmir (Perrigo, 2019).

One of the major hopes Pakistanis cherish is that if not the UN, the SCO can help resolve the issue of Kashmir. The hope is endorsed by Abdul Basit, as he says:

"Both Russian and China can play a role to reduce tension between India and Pakistan. Since China itself is currently in tension with India, Russia is better placed. Russia has enormous defence relations with India. After 1965 war, Russia invited both India and Pakistan to Tashkent to sign a peace agreement called the Tashkent declaration" (Basit, 2020).

In the Tashkent declaration was embedded the history of multilateralism in resolving regional crisis. The same can be expanded further to settle the Kashmir issue. Nevertheless, Jalil Abbas Jilani thinks that the SCO is not a forum meant for resolving quarrels, as the SCO denies the discussion on bilateral disputes amongst its member states at its forum. Jalil Jilani says:

"The SCO charter does not allow discussions on bilateral disputes among its member states. Pakistan is open to third party mediation in resolving the longstanding dispute of Jammu and Kashmir between Pakistan and India" (Jilani, 2020).

One of the reasons for the SCO to do so may be that the SCO learnt from the experience of the SAARC which remained handicapped owing to the Kashmir conflict between its two main members, Pakistan and India. Asif Durrani is of the view that the SCO would not get involved in bilateral issues. Asif Durrani says:

"Unfortunately, South Asia is the least integrated region and the SAARC, an organization of eight South Asian countries, remains hostage to Indian intransigence which is why it could not hold its summit for the past seven years. The SCO, on the other hand, has not allowed the bilateral issues of the member states to influence the decisions of the organization and this is a good omen for the promotion of this organization's aims and objectives. Certainly, Pakistan would be one of the beneficiaries" (Durrani, 2020).

Other than the issue of Kashmir, the SCO is replete with challenges of distraction. There are two main distractions to multilateralism that the SCO has been embodying. The first distraction is the lingering desire of Russia to join Europe and European institutions. Russian President Boris Yeltsin had a sincere desire to make Russia join NATO, but the dream could not be realized (Rachman, 2016). In 2000, Vladimir Putin argued that Russia was part of the European culture, and he could not envisage his country in isolation from Europe, the civilized world. He also said that it was hard for him to visualize NATO as an enemy. The subsequent events indicated otherwise. In August 2008, Russia invaded Georgia partially to initiate the first European war of the 21st century. The process of estrangement from the West became obvious further during The Ukraine crisis in late 2013 leading to the annexation of Crimea on 18 March 
2014. Russia was desperate to have its sphere of influence on the territory of the former USSR. On 29 May 2014, Russia also founded the Eurasian Economic Union (EAEU), which consisted of Eastern Europe, Central Asia, and Western Asia. The EAEU came into force on 1 January 2015. Nevertheless, at several international forums, including the United Nations, western diplomats noticed that the Chinese usually followed the Russian lead on most major issues such as nuclear negotiations with Iran or the Syrian peace talks (Rachman, 2016).

The second distraction is the persistent desire of China to reach out to developing countries of Latin America, Africa, and South Asia. China intends to diversify its accumulated wealth and savings by making big investments across the world. Moreover, China feels annoyed at the West for refusing it a greater role in the Bretton Woods institutions such as the World Bank (WB) and the International Monetary Fund (Gallagher, 2018). In 2014, China established the New Development Bank with Brazil, Russia, India, and South Africa (BRICS) that had an initial capital of $\$ 100$ billion. In 2014, China set up the Asian Infrastructure Investment Bank with $\$ 50$ billion in capital and the Silk Road Fund with $\$ 40$ billion. China also established a Contingency Reserve Arrangement to provide more financial safeguards across the developing world while presenting an alternative decision-making model to the WB and the IMF. The consequent effect is that the US considers China a global competitor. The Bretton Woods institutions have upgraded social and environmental standards and transparency to perform better and secure any credibility index. The "Dollar diplomacy" felt threatened by the "Yuan diplomacy" (Gallagher, 2018).

Despite the presence of these distractions, certain Pakistani analysts such as Saeed Shafqat are hopeful that both Russia and China can join hands to make the Asian century possible. Saeed Shafqat says:

"Economic growth in China and political stability in Russia since 2001 has led the two to put disputes and conflicts sideways, improve mutual trust and develop strategic and economic partnerships which are changing the dynamics of global order, boosting new economic and cultural partnerships and making the prospects of Asian century brighter" (Shafqat, 2020).

The concept of Asian century is driven by economic strides taken by an Asian country to shift the economic fulcrum from West to East (Chaulia, 2016).

\subsection{Interdependence offering Pakistan energy sources}

The post-9/11 era witnessed the palpable bend of the US towards India in the region of South Asia. Pakistan considers that the US has not helped Pakistan in the energy sector compared to the help the US offered to India, such as the 123 Agreement, US-India Nuclear Energy Deal in 2008 (Chaulia, 2016). Pakistan now hopes that China will help Pakistan overcome its energy crisis. The same is Pakistan's expectations from Russia.

At the platform of the SCO, Pakistan can forge better friendly relations with the CARs, as Pakistan intends to seek benefits from the natural resources of Kyrgyzstan and Kazakhstan. Though Turkmenistan is not a member state of the SCO, Pakistan has pinned its hopes on the Turkmenistan-Afghanistan-Pakistan-India (TAPI) gas pipeline project as an alternate route to reach the CARs. Mushahid Hussain Syed sees both the TAPI and SCO as close projects ready to yield energy benefits to Pakistan. Mushahid Hussain says: 
"We already have a major project, which is TAPI (Turkmenistan, Afghanistan, Pakistan and India) pipeline, and if agreement is there, we already have another project, that is, IPI (Iran-Pakistan-India) pipeline. Iran is an observer of the SCO and our major needs are going to be met through that. Turkmenistan has tremendous gas reserves. Kazakhstan is also major transit point for the Belt and Road Initiative (BRI), China and Europe via Kazakhstan... Tajikistan has tremendous hydal resources and there is already a project of Central Asia and South Asia (CASA) 1000 supply of electricity from Tajikistan. Pakistan's energy needs can be easily met through larger neighborhood of Central Asia having tremendous oil, gas and hydal resources" (Hussain, 2020).

The CASA-1000 project testifies the presence of energy-rich countries of Central Asia and energy-deficient countries of South Asia. The project envisions the supply of electricity from Tajikistan and Kyrgyzstan to Afghanistan and Pakistan. Further, Pakistan pins its hopes on the China Pakistan Economic Corridor (CPEC). Muhammad Samrez Salik thinks that developments under the CPEC would enhance Pakistan's energy needs, making it imperative for the TAPI pipeline and the CASA 1000 to get functional. Samrez Salik says:

"The CPEC related developments will warrant additional need for already energy starved Pakistan. In case, the North-South extension of the CPEC is successfully created, energy rich SCO countries can play a significant role for meeting energy needs of Pakistan as well as India. The CASA 1000 and TAPI pipeline are critical projects already in line for this purpose. However, these are being hindered due to instability in Afghanistan" (Salik, 2020).

Pakistan is fast getting energy deficient. Through its presence at the SCO, the foremost benefit Pakistan can get is to channelize the supply of electricity from the CARs, most of which happen to be members of the SCO. To meet this end, Pakistan has to enhance its role by developing better relations with the CARs to ensure electricity supply. Nevertheless, Abdul Basit thinks that Pakistan's dream to get energy from Central Asia cannot be realized if Afghanistan does not experience stability. Abdul Basit says:

"We can hugely benefit from natural resources in terms of TAIPI. We can realize its potential and we have CASA-1000 to import energy from Tajikistan. Similarly, we can also enhance our export to Central Asia, but the question is Afghanistan...If situation in Afghanistan gets better, there are opportunities otherwise not" (Basit, 2020).

The viability of Pakistan's effort to get energy from Central Asia depends upon the stability in Afghanistan.

\subsection{Pakistan offers a corridor to the SCO to reach the Middle East}

Through China, Pakistan offers a corridor to the SCO to reach the Arabian Sea and eventually the Middle East. In September 2013, under President Xi Jinping, China decided to develop a new Silk Road (or the Silk Road Economic Belt) across Central Asia to Europe (Rachman, 2016). The belt was a vision of a new Silk Road meant for recreating the ancient trade routes between China and its western neighbors in Central and South Asia. The road was the development of new trade routes in the seas around China, roughly along the routes once sailed 
by Admiral Zheng He during the Ming dynasty (Chaulia, 2016). In April 2015, President Xi paid a visit to Pakistan and signed infrastructure contracts worth $\$ 46$ billion with Pakistan (Rachman, 2016). President Xi also promised to direct \$1.6 billion towards developing Pakistan's port of Gwadar on the Arabian Sea. As a gesture of reciprocity, Pakistan signed a forty-year contract giving China the right to manage the port.

Saeed Shafqat opines that Pakistan should try to make the CPEC smooth and efficient. If Pakistan does so, it can reach its next destination, the economic zone created by Russia. Saeed Shafqat says:

"In order to be an effective corridor, we need to work in conjunction with Eurasian Economic Union (EAEU), which is led by Russia that will enhance the size and scale of trade and exportable commodities. India and Central Asian States are already doing it. Pakistan has an opportunity, if it makes CPEC smooth, efficient, hospitable and friendly corridor and focuses on exportable and importable commodities from both the SCO and the EAEU into the Middle East" (Shafqat, 2020).

Pakistan's destination, the EAEU, would not come with a cost, but Pakistan can reciprocate Russia by offering access to the Arabian Sea through the CPEC. Asif Durrani thinks that Pakistan should welcome the Russia's access to the Arabian Sea using the BRI and the CPEC. Asif Durrani says:

"Russia's access to the BRI or through the CPEC to warm waters would be welcomes by Pakistan and would also serve well to Pakistan's regional policy aimed at creating a peaceful and stable environment in the immediate neighborhood and beyond" (Durrani, 2020).

The destination of the CPEC is the Gwadar deep seaport in the mouth of the Strait of Hormuz. (Paul, 2014) Gwadar port has strategic significance for China, as Gwadar can be the answer to China's Malacca Strait dilemma (Richman, 2016). Further, Gwadar is not far from the Strait of Hormuz, which guards the entrance to the Persian Gulf, through which about $20 \%$ of the world's oil passes (Paul, 2014). Traditionally, for that oil to reach China, it had to sail around India and through the Strait of Malacca before entering the South China Sea (Richman, 2016). The port of Gwadar has made China get oil direct from the Persian Gulf (or the Arabian Sea) through the motorway constructed under the CPEC, which could enhance the supply of oil from both the Middle East and Iran. From Gwadar, the oil can be transported overland, across a 3,000-kilometer land route into western China. In a way, over the years, what China could spend by transporting the oil through the sea route could be invested in Pakistan to develop the mesh of infrastructure ranging from road, railways, and pipelines to make those shipments possible (Richman, 2016). China also decided to make infrastructure investments in developing the String of Pearls stretching from the Chinese port of Hainan across the Indian Ocean to the Middle East and Africa (Plater-Zyberk, 2014). The sea lanes would permit China to export manufactured goods and import energy resources for its Eastern half. To allay the fears of India, in September 2014, China's President Xi Jinping visited New Delhi and pledged to invest $\$ 20$ billion in the infrastructure of India (Majumder, 2014).

Through the SCO, the route to the Arabian Sea is opened for Russia by bypassing Afghanistan. Huma Baqai opines that Russia desires to get benefit of the CPEC. Huma Baqai says: 
"Russia has shown a tangible desire to be part of China-Pakistan economic corridor. In fact, Russia has also proposed Russia-Pakistan economic corridor. This indicates a paradigm shift in the policy how Russia used to view these countries whereas in the past it thought the regime change was the only option to achieve its objectives" (Baqai, 2020).

In Asia, the priority of Russia seems to be economic cooperation and not a military invasion. Russia is looking towards the east and is no more aspiring for any hegemony. Whether it exists overtly or covertly, Russia's yearning to reach the warm waters of the Arabian Sea need not be viewed through the colonial mindset of keeping Russia at bay even by instigating Afghanistan to act as a buffer state (Paul, 2014). Neither is Pakistan a legacy of colonialism to uphold the colonial mindset nor is Afghanistan a buffer state. The realities on the ground have changed. Today's Afghanistan needs peace and a vibrant economy to make possible a good survival of its citizens instead of relying on opium trade (or drug money) and earning infamy. On the other hand, Pakistan is conscious that reducing the former USSR to today's Russia has not rendered Russia bereft of natural and artificial resources (or manufactured). Pakistan needs to seek more benefits from its improved relations with Russia at the platform of the SCO.

\section{Critical analysis}

There are four facets of criticism. The first facet of criticism is that the SCO is primarily a Russia-China alliance, and the world looks at its two treaties with suspicion. The first is the Treaty of Friendship, which calls for increased military cooperation including the exchange of military technology between Russia and China, though the treaty also encompasses cooperation in trade and social sectors, and it was signed on 16 July 2001 (Tyler, 2018). Out of 25 Articles, Article 9 of this treaty implies a kind of defense pact between Russia and China, and Russia recognizes China's stance on Taiwan. In May 2014, Putin visited China and laid emphasis on the strategic closeness through joint naval exercises staged by the two countries in the East China Sea that year, and in the Mediterranean Sea the following year (Rachman, 2016).

The second treaty is called the Collective Security Treaty Organization (CSTO) was signed in October 2002 between the SCO member countries to make it's a military alliance (Gorenburg, 2020). The CSTO was formed on 15 May 1992 between Russia and six ex-USSR states such as Armenia, Kazakhstan, Kyrgyzstan and Uzbekistan. The CSTO is also called the Tashkent Pact (or Tashkent Treaty). In 1994, another three ex-USSR states such as Azerbaijan, Belarus and Georgia joined the CSTO (Gamerman et al., 2020). On 19 December 2012, Uzbekistan withdrew from the treaty. Taken together, both treaties give the impression of the presence of a military alliance in Eurasia.

The second facet of criticism is that Gwadar is useful for expanding the Chinese navy (Rachman, 2016). The possibility has raised fears in both New Delhi and Washington coupled with the fact that $\mathrm{Xi}$ agreed to sell Pakistan eight advanced Chinese-made submarines. The development is replete with repercussions. Mushahid Hussain Syed thinks that the Indian Ocean is about to become a battleground for a new cold war. Mushahid Hussain says:

"The Indian Ocean is going to be a major battleground for the new cold war. Already, there are 120 navy warships in the Indian Ocean today. China and Pakistan are going to be important players, and India and the US are already there along with other countries" (Hussain, 2020). 
There is a possibility for growing tension in the Indian Ocean or precisely in the Arabian Sea. Rabia Akhtar opines that the extension of China to Gwadar may be the major concern of the US. Rabia Akhtar says:

"The major concern of the US is about China, which is perching itself in the Indian Ocean with an eye on the Strait of Hormuz. Obviously, Russia is one of the biggest threats to the US national security, and the US feels that Russia may find China's BRI as a springboard to its resurgence. I do not rule out the US showing this concern as and when the CPEC is fully functional" (Akhtar, 2020).

It simply means that the development of the CPEC and Gwadar are a source of regional and international tension to face which Pakistan should be ready. Currently, Pakistan has been facing pressure from various friendly Arab countries to abandon the CPEC and the development of Gwadar (Paul, 2014).

The third facet of criticism is that Russia and Pakistan are mending fences. From 1979 to 1989, Pakistan and the former Soviet Union, now represented through Russia, remained involved in a war in Afghanistan, called the Afghan Jihad. The way Russia and Pakistan are mending fences after 1991, it means that both countries have reached the conclusion that the past should not dictate the present. That is, both the countries should not remain prisoners to the past; instead, both should construct a new kind of future at the platform of the SCO. Mushahid Hussain Syed thinks that Russia's effort to reach the warm waters of the Indian Ocean after conquering Afghanistan was a myth. Mushahid Hussain says:

"I do not think Russia has any attempt to desire to reach the warm waters of the Indian Ocean. This was a myth of the cold war. It has been found now in the archives of the Soviet Politburo that the decision to go into Afghanistan has nothing to do with warm waters of the Indian Ocean. Everything was to do with the situation inside Afghanistan" (Hussain, 2020).

After fighting a decade long war called the Afghan Jihad, many Pakistani analysts project the thought that Russia had no intention of attacking Pakistan to reach the warm waters of the Indian Ocean. This argument mollifies Pakistan to let Russia be part of the CPEC to reach the Arabian Sea for trade.

The fourth facet of criticism is that Pakistan's association with the SCO and the CPEC has raised concerns of the West. Nevertheless, on the question of the West, the house is divided. There are two schools of thought. The first school of thought says that the West is worried about the development. Saeed Shafqat is of the view that the West's worry is the BRI and the CPEC. Saeed Shafqat says:

"The West's worry is the BRI, Maritime Silk Road and CPEC as an outlet to the Persian Gulf, the Arabian Sea and into the Indian Ocean" (Shafqat, 2020).

One of the major external challenges to the development of the SCO would come from the Western countries.

Huma Baqai says that the West is suspicious of the nexus between Russia and China expressed through the SCO of which Pakistan is a member. Huma Baqai says: 
"Russian Chinese nexus is a 21rst century reality and it still has to reach its potential. Pakistan as a state is very much open to the West which does not allow the true potential of the region to emerge, but there is a very perceivable shift in Pakistan's foreign policy. We need a more assertive Russia and a more assertive China, all of them come together to allow the potential of the SCO... Europe is skeptic, as it does not see the CPEC as an economic initiative. Europe sees it as a geo-political initiative, which would enhance the influence of China especially in Europe and Asia as strategic influence of China through one belt one road" (Baqai, 2020).

The SCO is seen in the context of the CPEC to enhance the influence of Russia and China in the India Ocean as a geo-political strategy. Nevertheless, Mushahid Hussain Syed thinks that the West derides the CPEC because it represents economic emergence of China offering a direct challenge to the economy of Europe. Mushahid Hussain says:

"For the West, the main issue is not the CPEC; it is China, the peaceful rise of China. China's emergence, as predicted by the World Bank and IMF is that in 2024, China will be the number one economy of the world. So that is the main fear of the western countries, and it is nothing to do with the CPEC. As the CPEC is part of China-Pakistan relations, hence it is a concern... The SCO has a combination of political and economic cooperation. In these times, one cannot separate economic from politics. It is geo-politics and also geo-economic" (Hussain, 2020).

The US policy is that geo-politics is more important than geo-economic. The presentence of both together is a lethal combination. Muhammad Samrez Salik opines that China's access to the Indian Ocean through the CPEC is bound to become a major source of tension. Samrez Salik says:

"In the new global arrangements, Russia and China are being viewed as part of one bloc. The 1980s was consumed by the West to block the Russian effort to reach warm waters. The West feels that the same has been now facilitated through the CPEC. The Indian Ocean is also being tipped as center stage of rivalry for the 21 st century. Access of China through the CPEC would play a pivotal role in future rivalry. However, the West's interests to block Russia's access to the Indian Ocean are no more aligned with Pakistan's interests as happened in the last century" (Salik, 2020).

It simply means that Pakistan may come under pressure owing to the CPEC because it is meant for enhancing the influence of China in the Indian Ocean.

The second school of thought says that the CPEC does not harm the interests of the West. Rabia Akhtar opines that the real threat that the West faces comes from the disposition of the US for preferring geo-economic to geo-politics. Rabia Akhtar says:

"It would be inaccurate to say that the CPEC is harming the interests of the West. It is the West that is calling the BRI a manifestation of China's predatory economics challenging the so-called rules-based order in the Indo-Pacific area. The CPEC reduces China's reliance on the Strait of Malacca and, hence, 
hampers the US' ability to choke China. The CPEC also provides a soft counterweight to the US' militaristic policies in the Middle East. The real threat that the West faces from the BRI and the CPEC emanates from the US' willingness to give precedence to geo-economic over geo-politics, something that China continues to do with finesse" (Akhtar, 2020).

It means that the West is least concerned about the CPEC or the SCO, but it is the US, the policies of which in the Indian Ocean and the South China Sea are raising the threat level for the Western countries.

All the four facets of criticism focus on different aspects of the given issue highlighting impending challenges to Pakistan's willful association with the SCO. Given the situation of tottering democracy and fragile economy, all the four facets also offer a source of distraction to Pakistan.

\section{Conclusion}

Throughout 2015, the SCO has become a globally prominent organization. Its structure and goals have evolved throughout time, although it has been in the nascent stage. In 2017, the SCO gave Pakistan and India permanent membership status at the Astana summit of heads of state. After China, both are important players in South Asia. The Astana summit provides Pakistan with a new direction in its foreign relations, which might help its economy. The CPEC is the backbone of China's BRI. After the CPEC is completed, Gwadar would be the closest and largest harbor for all landlocked countries. This component of CPEC will be vital for all Central-West Asian nations completing BRI. BRI will assist Pakistan, China, and other neighbors economically. Since the US, India, and Japan have misgivings about these intentions, Pakistan must behave carefully. Pakistan's strategic location makes it a center to Central Asian, South Asian, and Russia-China commerce. Pakistan's position in Asia is excellent for providing the quickest maritime access to landlocked countries. This privileged situation of Pakistan can boost trade and integration links. Therefore, Pakistan's permanent SCO membership at the Astana summit has improved its connections with all member nations, particularly the CARs, while also allowing Pakistan to address its border, energy, and economic concerns. Pakistan must seize this chance.

The SCO is still in the formative phase and needs further time and experience to become a fullblown functional organization. The SCO has to come out of its theoretical approaches to make plans and opt for the implementation of the plans. Pakistan has to wait for the maturity of the SCO to play its role. Offered by the SCO, multilateralism is leaving its calming effect on regional conflicts, but multilateralism has been facing certain challenges of distraction. Both the main members of the SCO are focusing on extra-regional organizations such as Russia is developing the EAEU to get a better access to Europe whereas China is developing its links with the developing countries of South America, South Africa and South Asia. As a developing country, Pakistan can play its role in attracting investment in its infrastructure sector including the ongoing CPEC related projects.

The SCO countries embracing the CARs (such as Kyrgyzstan and Kazakhstan) having natural resources such as gas and oil are a major source of attraction for Pakistan, which a developing and an energy-strived country. Turkmenistan, which is not a member of the SCO, can be a major source for gas under the TAPI project but the pipeline has to pass through Afghanistan 
which is still deficient in peace. The same is true for the CASA-1000 project of bringing electricity from Tajikistan. Pakistan can get energy (gas or electricity) from Central Asia but reciprocating the CARs with offering them access to the Arabian Sea through the CPEC project run by China. Pakistan's overreliance on the CPEC offers Pakistan certain challenges posed by Pakistan's friendly countries in the Middle east and Europe, besides the US itself. Run under the BRI, the CPEC opens space for China to get an alternate route and short access for its products to the Arabian Sea. Besides, the development of any navy base for China at Gwadar is fraught with additional repercussions. There is a possibility for more presence of more military vehicles in the Indian Ocean.

Pakistan's evolving role is promising in the sense that the SCO gets mature, implement its plans and get fully functional. Further, Pakistan's evolving role depends on multiple factors such as the viability of the SCO, the power of convergence of interests of both Russia and China and the weakening of external pressures from Pakistan especially from friendly Arab and Western countries. In the eyes of the SCO, Pakistan can reciprocate by enhancing its importance through the CPEC and Gwadar by offering the SCO countries a geo-political and geo-economic link to the Middle East.

\section{Declaration of conflict of interest}

The author(s) declared no potential conflicts of interest(s) with respect to the research, authorship, and/or publication of this article.

\section{Funding}

The author(s) received no financial support for the research, authorship and/or publication of this article.

\section{References}

Ahmad, N. (2017, July 2018). India's and Pakistan's membership diminishes SCO's ability to compete with NATO. The Central-Asia Caucasus Institute Analyst. https://www.cacianalyst.org/publications/analytical-articles/item/13457-india's-andpakistan's-memberships-diminishes-sco's-ability-to-compete-with-nato.html

Aris, S. (2013, December). Shanghai Cooperation Organization mapping multilateralism in transition No. 2. International Peace Institute. https://www.ipinst.org/wpcontent/uploads/publications/ipi_e_pub_shanghai_cooperation.pdf

Chan, J. (2008). Russia and China settle longstanding territorial disputes. World Socialist Website. https://www.wsws.org/en/articles/2008/08/ruch-a14.html

Chaulia, S. (2016). Mode doctrine: The foreign policy of India's Prime Minister. Bloomsbury. https://www.bloomsbury.com/in/modi-doctrine-9789386141156/

Cohen, S. P. (2016). The South Asia papers: A critical anthology of writings. Harper Collins.

Fayyaz, D. S. (2019). Pakistan and the SCO: Aspirations and challenges. Journal of Political Studies, 26(1), 95-102. $\quad$ http://pu.edu.pk/images/journal/pols/pdf-files/6v26_1_19.pdf

Gallagher, K. P. (2016). The China triangle: Latin America's China boom and the fate of the Washington consensus. Oxford University. 
Gamerman, S. R., Romaniuk, M., Thapa, P. M., \& Cham. (2020). Collective Security Treaty Organization. The Palgrave Encyclopedia of Global Security Studies.

Gorenburg, D. (2020). Russia and collective security: Why CSTO is no match for Warsaw Pact. Russia Matters. https://www.russiamatters.org/analysis/russia-and-collectivesecurity-why-csto-no-match-warsaw-pact

Haass, R. (2017). A world in disarray: American foreign policy and the crisis of the old order. Strategic Studies, 38(3), 108-110. https://www.jstor.org/stable/48539389

Johnston, S. A. (2017). How NATO adapts: Strategy and organization in the Atlantic Alliance since 1950. Johns Hopkins University.

Khetran, M. S. (2019). SCO Membership and Pakistan: Prospects of relations with Central Asia. Strategic Studies., 39(2), 2-5. https://www.jstor.org/stable/48544301

Majumder, S. (2014 September 18). China's Xi Jinping signs landmark deals on India visit. BBC News. https://www.bbc.com/news/world-asia-india-29249268

Nisa, Z. U., Mustafa. G., Naeem. M., \& Sattar, S (2021). Pakistan and Shanghai Cooperation Organization (SCO): An analysis. JRSP, 58(2), 106-113. http://pu.edu.pk/images/journal/history/PDF-FILES/14_58_2_21.pdf

Noorani. A. G. (2011). Article 370: A constitutional history of Jammu and Kashmir. Oxford University.

https://oxford.universitypressscholarship.com/view/10.1093/acprof:oso/9780198074 083.001.0001/acprof-9780198074083

Pedro. N. D., \& Viilup. E. (2015). Misunderstandings and tensions, a new normality in EURussia relations? Notes Internacionals CIDOB. https://www.cidob.org/en/publications/publication_series/notes_internacionals/n1_1 15 incomprension_y tensiones_como_nueva_normalidad_en_las_relaciones_ue_ru $\underline{\text { sia/misunderstandings_and tensions_a new normality_in_eu_russia_relations }}$

Perrigo. B. (2019). The Indian government is revoking Kashmir's special status. Here's what that means. Time. https://time.com/5644356/india-kashmir-article-370/

Pilger, J. (2016). The new rulers of the world. Verso.

Plater-Zyberk, H., \& Monaghan, A. (2014). Strategic implications of the evolving Shanghai Cooperation Organization. Strategic Studies Institute, US Army War College. http://www.jstor.org/stable/resrep11392

Paul, T. V. (2014). The warrior state: Pakistan in the contemporary world. Random House.

Rachman, G. (2016). Easternisation: War and Peace in the Asian Century. Penguin.

Rana. A. I. (2017, June 09). Historic day: Pakistan joins SCO at Astana Summit. Tribune. https://tribune.com.pk/story/1431365/pakistan-becomes-full-member-shanghaicooperation-organisation

Steinberg. James. Michael E. O'Hanlon. (2014). Strategic reassurance and resolve: US-China relations in the Twenty-First Century. Princeton University Press.

Sayed. B. S. (2017). Explainer: What joining SCO means for Pakistan. Dawn. https://www.dawn.com/news/1338546

Turner, S. (2009). Russia, China and a multipolar world order: The danger in the undefined. Asian Perspective, 33(1). 159-184. https://muse.jhu.edu/article/713301/summary

Tyler, P. E. (2001). Russian and China sign 'Friendship' pact. The New York Times. https://www.nytimes.com/2001/07/17/world/russia-and-china-sign-friendshippact.html

Weitz, R. (2008). Russia, China end decades-long border dispute. World Politics Review. 
Zeb, R. (2018). Pakistan in the SCO: Challenges and prospects. The Central Asia-Caucasus Analyst. $\quad$ https://www.cacianalyst.org/publications/analytical-articles/item/13496pakistan-in-the-sco-challenges-and-prospects.html

Ziauddin, M. (2017, July 10). Strategic implications of SCO. Express Tribune. https://tribune.com.pk/story/1431652/strategic-implications-sco

\section{List of Interviews}

Akhtar, D. R. (2020, July 22). China Pakistan partnership and concerns for U.S. (D. T. Aslam, Interviewer)

Akhtar, D. R. (2020, July 22). Origin of SCO and its consequence . (D. T. Aslam, Interviewer)

Baqai, D. H. (2020, July 16). Russia and Pakistan future with CPEC. (D. T. Aslam, Interviewer)

Basit, A. (2020, July 16). Pakistan relations with the CARs. (D. T. Aslam, Interviewer)

Basit, A. (2020, July 16). SCO possible role in resolving Kashmir issue. (D. T. Aslam, Interviewer)

Durrani, A. (. (2020, July 21). SCO in its initial stage and needs time. (D. T. Aslam, Interviewer)

Durrani, A. (2020, July 21). (D. Tehmina, Interviewer)

Durrani, A. (2020, July 21). Russian access to Arabian Sea using BRI and CPEC. (D. T. Aslam, Interviewer)

Durrani, A. (2020, July 21). SCO and member states bilateral issues . (D. T. Aslam, Interviewer)

Hussain, S. M. (2020, July 25). Indian Ocean and the new Cold War. (D. T. Aslam, Interviewer)

Hussain, S. M. (2020, July 25). TAPI, SCO and energy benefits for Pakistan. (D. T. Aslam, Interviewer)

Jilani, J. (2020, July 20). SCO charter and Kashmir issue. (D. T. Aslam, Interviewer)

Jilani, J. A. (2020, July 20). Indicators of meausring SCO success. (D. T. Aslam, Interviewer)

Salik, S. (2020, July 13). Pakistan energy needs and CPEC. (D. T. Aslam, Interviewer)

Shafqat, S. (2020, July 13). Pakistan targeting economic zones of Russia after CPEC success. (D. T. Aslam, Interviewer)

Shafqat, S. (2020, July 13). SCO and new economic and cultural partenrships . (D. T. Aslam, Interviewer) 


\section{Appendic: List of interview questions}

Q1: How can the CPEC help the SCO countries of Central Asia use the corridor to export their products to the Middle East?

Q2: To what extent can the SCO membership help Pakistan meet its energy needs with the import of oil and gas?

Q3: How would you comment on the statement that the SCO has not being performed much because it is not a truly economic or political bloc led by Russia and China?

Q4: How would you comment on the statement that the SCO has helped both Russia and China to resolve their mutual conflict and come out of isolation imposed by the postCold War democratic and capitalist world?

Q5: To what extent can the SCO membership help Pakistan extend its trade interests in Central Asia?

Q6: What role can the SCO play to make its members, Pakistan and India, reduce mutual tension between them?

Q7: To what extent has the SCO membership raised Pakistan's role and image in the region of South Asia?

Q8: Does the SCO hold the potential of becoming an economic bloc or a political bloc in Asia Major?

Q9: To what extent has the CPEC raised the western concerns over Russia's attempt to reach the warm waters of the Indian Ocean (or the Arabian sea)?

Q10: How is the CPEC harming the western economic interests in the region of South Asia and Middle East? 